\title{
Capful Dosing Unit
}

National Cancer Institute

\section{Source}

National Cancer Institute. Capful Dosing Unit. NCI Thesaurus. Code C102405.

A dosing measurement based on the capful unit. 